\title{
The Effects of Replacing Groundnut Cake with L'rea- Treated and Fermented Brewer's Dried Grains on Nutrient Digestibility, Retention and Carcass Characteristics of Broiler Finishers
}

\author{
J. O. Isikw enu", O. J. Akpodie1c, S. L. Omeje and CiO. Okagbare

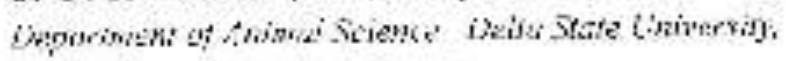

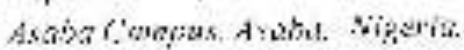

\section{Alistract}

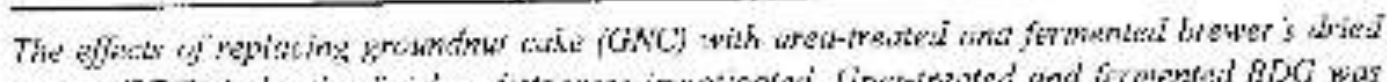

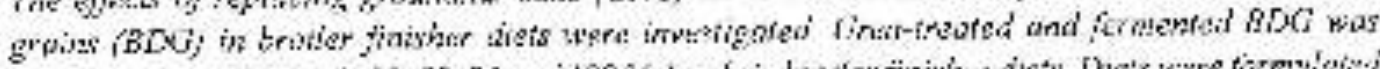

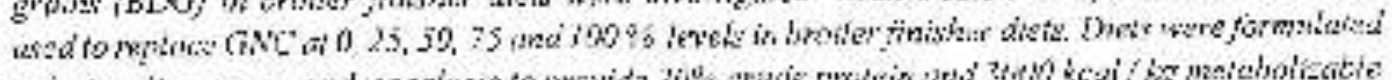

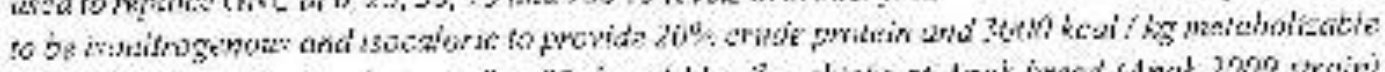

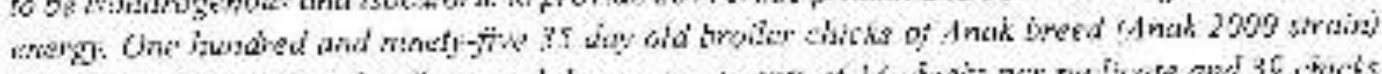

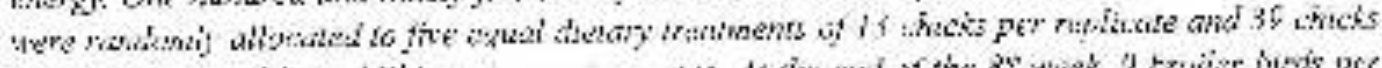

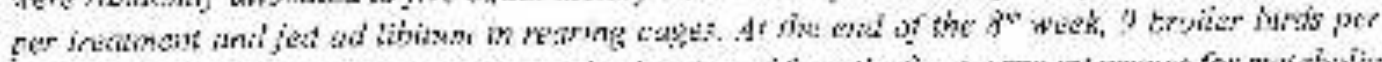

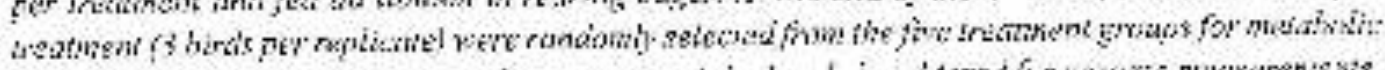

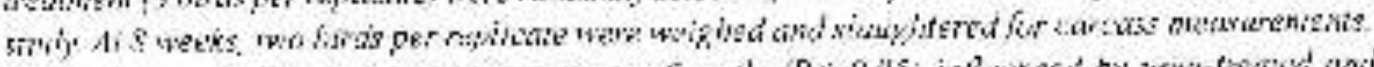

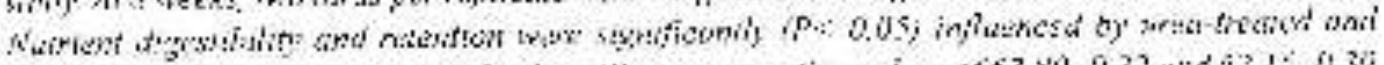

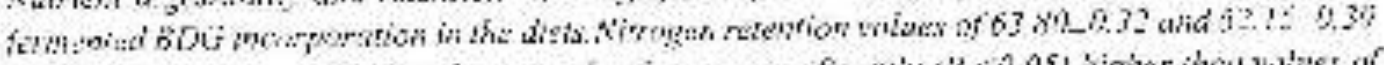

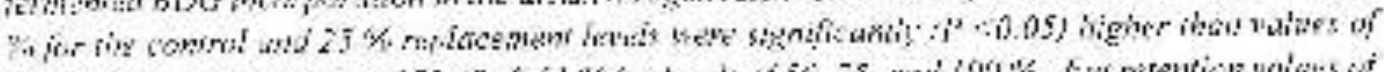

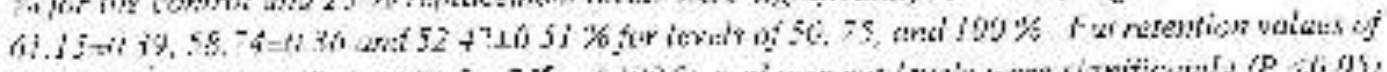

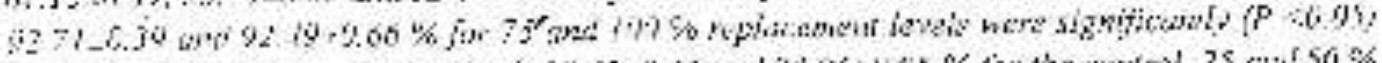

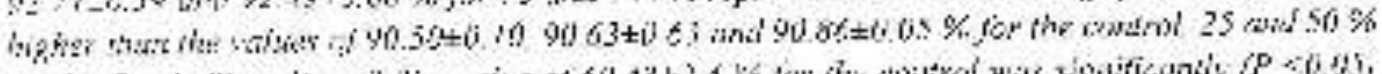

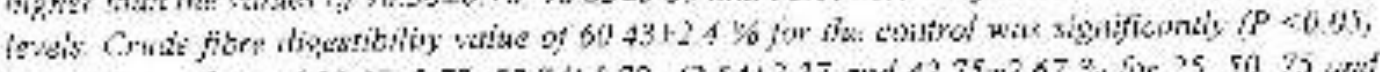

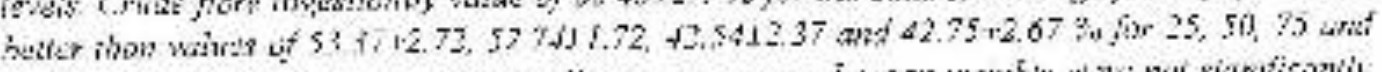

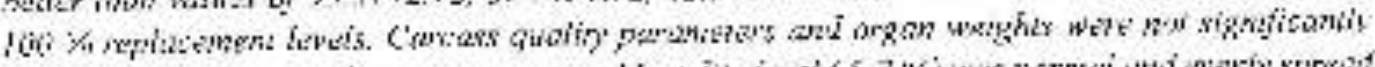

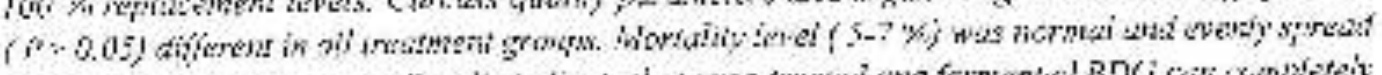

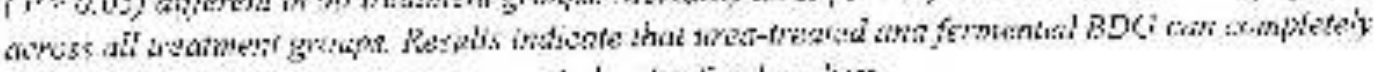

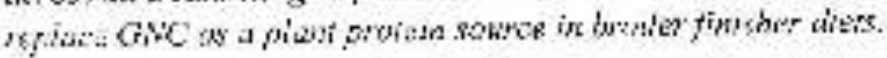

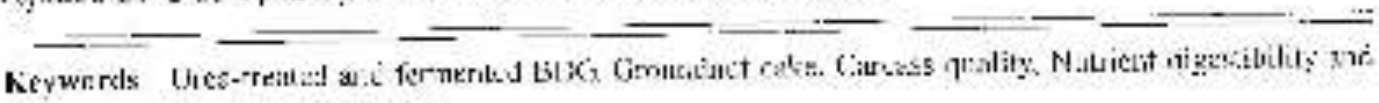

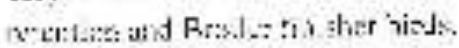




\section{Introduction}

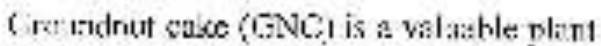
zoterr. source as at: of the curventioual agro-

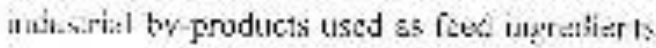
in renogestric feet. I lowever the oyst of Git:

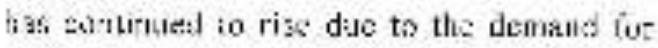
groundrut and grsallstrul by'-products by man

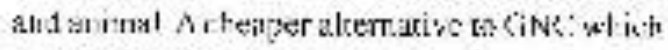
is readily sveilabie and ant tirsclly respiad by

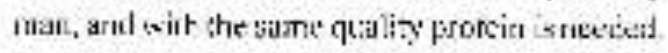

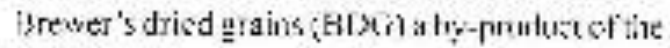
bewile a ti. ry rres: thase requixemsnte and wan be used is an aitsmative wo (iNC: siace they

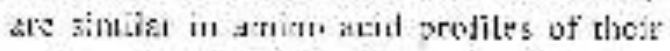

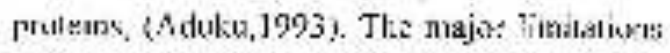
to the ase of $B\left[x C_{i}\right.$ as a source of plant protein is its tigli: sutte libe content (Onsudike, 199\%;

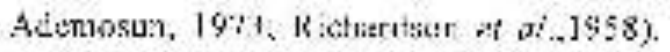
- vine provessine of BDG in ads we ithee its f:bus lavet is liserefore imperative. Aikali Ireatmert have bee: usad to imprave the nutrianst qualit of uterous expg residues or by-

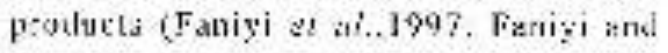

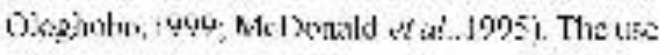

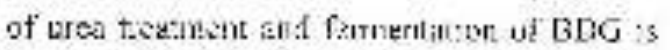
expecita lo breik:iown an 3 roduce the fibre coatem and therefsoc irake I prosstele to

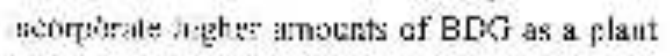

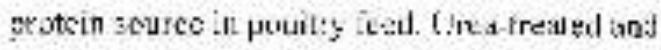

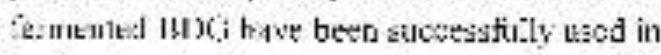
eroiler starter ciists as a roplace ne or for GNC:

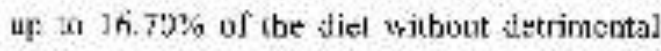

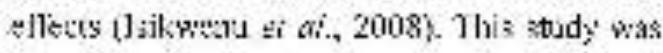

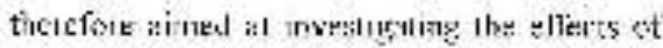
rezlieirar GNE with use-trcated and femsented BDG an le nutraenl nitieation. cartiss thata:teriztizs ald wrgan sejghts of broils linishers.

\section{Whaterials and Methords}

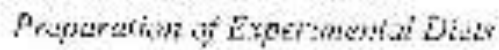

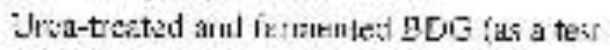
angedient; was used ro seplace fround at take

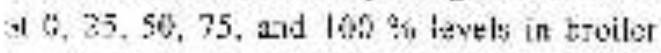
finsher thist en proieill owuivalen: basis. The

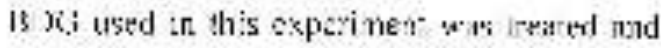
ferracented for 7 taws usiag $2 \%$ uren concoutration arid wils prepired by til: usetiud of sileleys (1)88j. Tac proxumale conpoxitions of the arsatreat:d and it rmented Bly; and the untreated BDG ase presented in Table: ., live diens were fomblated to lse snvi rayenous and isocalctic

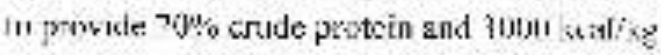
rectabslizable enceys. töle diefs rewe adequately furcishoud mits vitamins and minerals. The ompesitions of tie brosler fieisber diets ar: pretenles: in Taible 2.

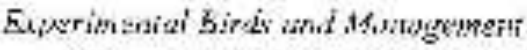

one ruadred and nivery five is why att hwiler ta cks of A Jatk breed (Ánzk 200? savais) were rundonty allocated irke five: listuriects ot

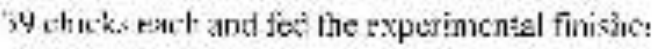

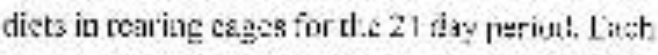
tica:m-nt wis replis:itre: tbrice wath 13 chicks per reglicate Feed and water were pimvidet at Stbinios:

\section{Metabori: $\gamma_{\text {ratis }}$}

Al lite entul of ? ldy's when they were $S$ weeks ol: 9 aroils birds por treatmert (3 b.rds.

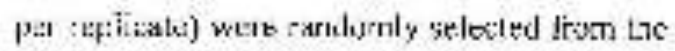
live treatment groups ther metabolic at.rd: afier 


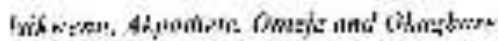

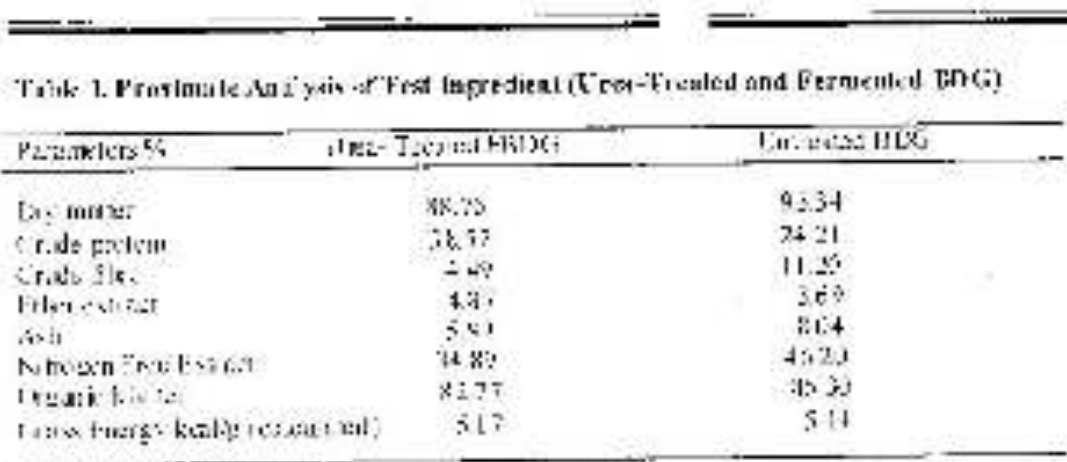

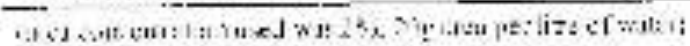

Thi Y.umsmal allo:

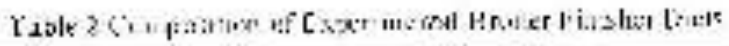

\begin{tabular}{|c|c|c|c|c|c|}
\hline \multirow{2}{*}{ Re vateme-n, t.kv ds ivi } & \multirow{2}{*}{ 1 0} & \multicolumn{2}{|c|}{ C.s.lngy lintilinents } & \multirow{3}{*}{$\begin{array}{l}79 \\
7\end{array}$} & \multirow{3}{*}{$\begin{array}{l}1 x \\
5\end{array}$} \\
\hline & & $2 j$ & 50 & & \\
\hline I.gredins & $1 \mathrm{i}: 2 \pi=1$ & 3 & 3 & & \\
\hline P-1:ize $(y \mid k)$ & $x .2 \mathrm{~J}$ & $5 \%$ & $5 S \%$ & $34 . \overline{5.5}$ & 37.85 \\
\hline Cra & 21.51 & I $1:: 2$ & 111.75 & 5.33 & - \\
\hline I 7 inl & - & 5.3 & 1.1. & $: 4,37$ & 26:.:1: \\
\hline Et: h ourtal & $\because$ ร11 & $2 . \bar{Y}$ & 2.20 & 2. it: & 2.50 \\
\hline Hilo:ad rail & ; stl & 3.51 & 3.59 & ! s: & 3.54 \\
\hline 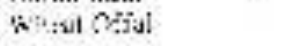 & , 1.0 & s.:। & 3.113 & $(x)$ & 3.00 \\
\hline Ki:e LItas & 16 & 1.113 & i.to & 10 & 15: \\
\hline Bore ir:e & $20 \%$ & i.t:i & 3i:il & 30 & is: \\
\hline inser $5: a$ & $1: r$ & 1.34 & I. sli & 159 & $: 6$ \\
\hline [ t.z: $: 1$ & $3 \%$ & 2. 2ก & $\because$ is & 315 & 45 \\
\hline Freveraiol:ierre & i) 50 & $y=1$ & a.t. & $8 \%$ & $1: 0$ \\
\hline 8 & II: & $\therefore \quad: 1$ & $y=c$ & i) $<.1$ & 1.0 \\
\hline 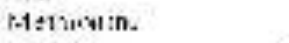 & 1: $\leq 1$ & $\therefore: 1$ & 13 & 11. $\div 1$ & $\therefore \therefore$ \\
\hline rotsi & i vu.uo & 11111.80 & IIIII AR: & 11:-11..11 & ItIIIIII \\
\hline Cutmital Inalnsa $11 \%$ & diclalably. & & & & \\
\hline 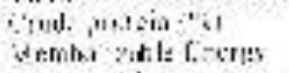 & $\because 1=$ & il: 24 & 211.2 & sis & $15.4 \mathrm{i}$ \\
\hline$\because 1 / k=1 k=$ & ar. ir & 30280 & 㩆 & $2 \cdot 21+4 \%$ & $5052 \times 4$ \\
\hline \multicolumn{2}{|c|}{ Theacical tenilysio i Drorermeedli } & & & & \\
\hline Indrut: & $29: 3$ & $\theta+42$ & 5): $: 5$ & 40,5 & $8 k 13$ \\
\hline Cink glos: & $2.17 \cdot$ & -20.37 & 8.4. & $24<4$ & $2 \pi$ \\
\hline Erab Thr: & s $x^{2}$ & 650 & 1.3.3. & 73 & 7.31 \\
\hline Glu+resurest & $\therefore<0$ & 807 & 327 & 3.5 & $3.6 \%$ \\
\hline 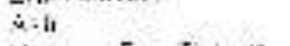 & 3.35 & $1 \%$ & 1340 & $11 . \leqslant$ & $11+5$ \\
\hline N maz̧er Tros I sin:1 & 31.23 & $5 \%:-$ & 840 & 17.55 & 4365 \\
\hline
\end{tabular}




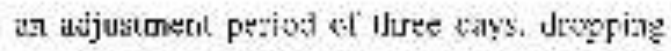
trays covexed witi alumiziura thil naper wers

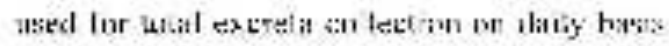
for time drys. Feed intake oiver the three days

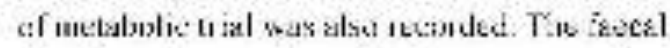
dreppings trom sach replicate wese oven ar.ad at low temperature ranging fiom $60-80^{2} \mathrm{C}$ to

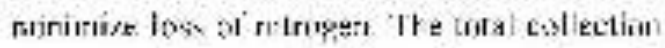
were pooled wetghed and grword; and

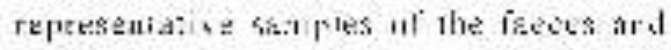

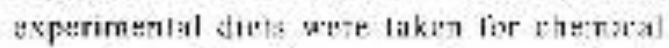
dolysis of their respectide petaimate

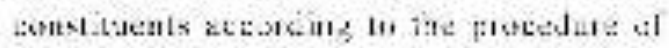

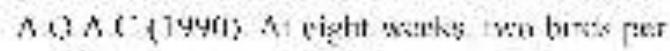
repticate grou. fasted ove: night acec

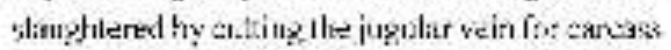
r.casurements atte: the pre-s]avgher weights nert recoriled.

\section{Dula Anviozis}

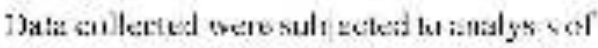

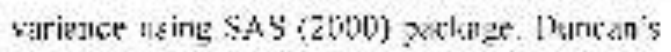
Multiple Range Test (Dhean. 1955) was us.d

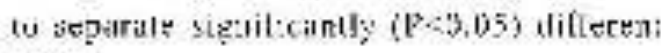
means.

\section{Resuits}

The issuts of the perion hatee of Mosilet: fed the linishe: die as ac prewentad in lisble : The results of the nucriest tigestibility and seteation of hroiler hirds at cight weeks of age fed ibe linisbe: die:ti are presenled in lable 4 . The nithgen retention, snuds fibec and diy metrel

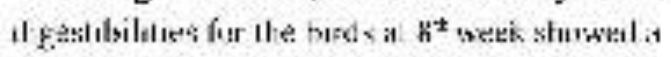
significant (Fou 0s decrease as the levels of

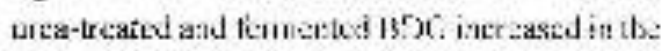

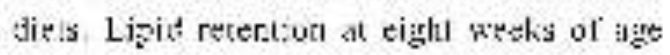

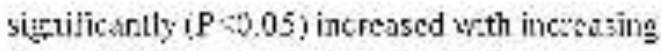

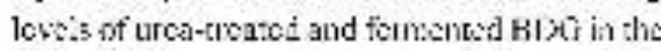

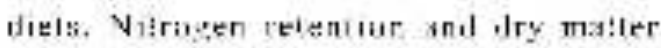
digestibility of broi ens led the sontro diet ano stguificantly $(\mathrm{P}-0.05)$ highet tha those fer

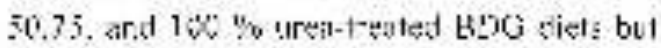
similar 20.051 with boulers fed 25 st uxe2-

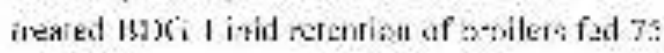

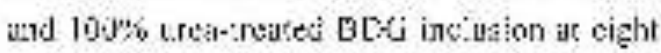

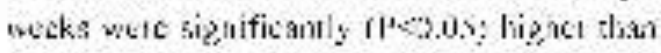

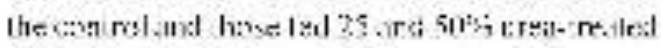
BDC. Broler tintiers fo the zorteol dicts wert serifizatly (T-a.a), better than al: u-lear

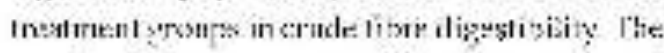
asults of the sercass quatity naranoters and organ we ph: incissuccusents of the heriler.

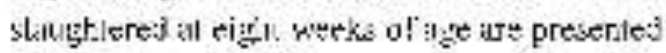
in labies .5 ca: 6. A 7 pa.anteter ent sidered fos

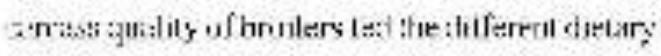
twamenta xers rot seqnificataly (P.o.t.5)

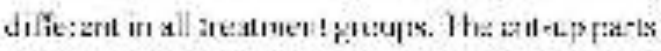
were also nat sizniticantly (4) 05 ij differeat. with the cscepion. of the brosst anc nck. Th:

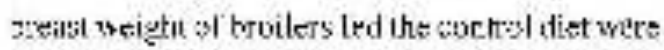
similer ( $\mathrm{P}: 6.05$ ) to all trearnort $\leqq 10 u p s$ zxcep:

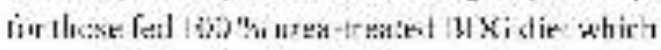

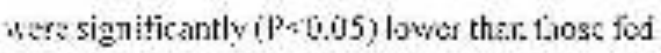

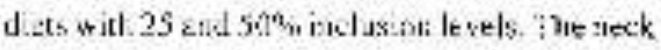
welyal ul buele-s led diet will: $75 \%$ inslosion

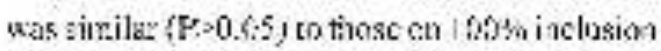

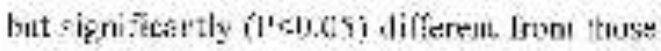
al 4,25 unc $5 \%$ inclusion evels Moat of the

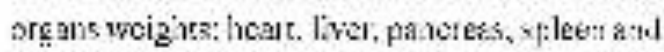

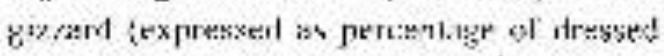
weieht) uere net siguiticantly (F.0.05) Jifferent

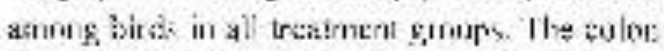

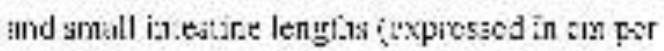




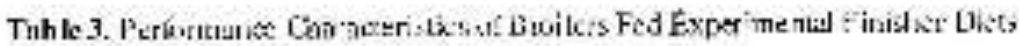

\section{Cint ry liestintes}

\begin{tabular}{|c|c|c|c|c|c|}
\hline Re fli:ez.ncut Leted: ( $\%$ ) & DIL $L \mathrm{BD} \mathrm{i}$ & 2SUTRDA: & SAL $\mathrm{SBCA}$ & r5uThix: & 10 \\
\hline & LaxXive: & $\because 3 G N C$ & socits & 150 No: & $\operatorname{arct} x$ \\
\hline acanctes.i & 1 & 2 & 3 & 4 & 5 \\
\hline
\end{tabular}

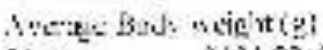

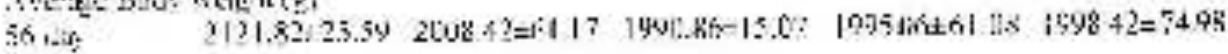

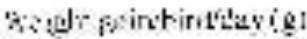

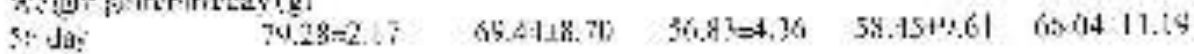

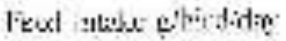

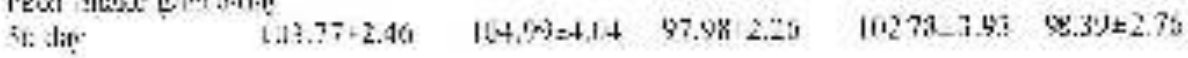

Feel: (i.in reiv

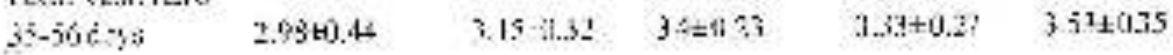

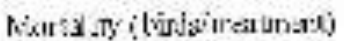

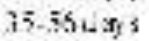

o.

2

2

3

3

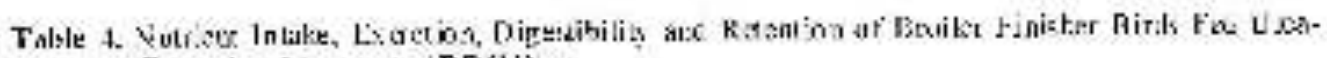
Friared and kermiluter RDGildes

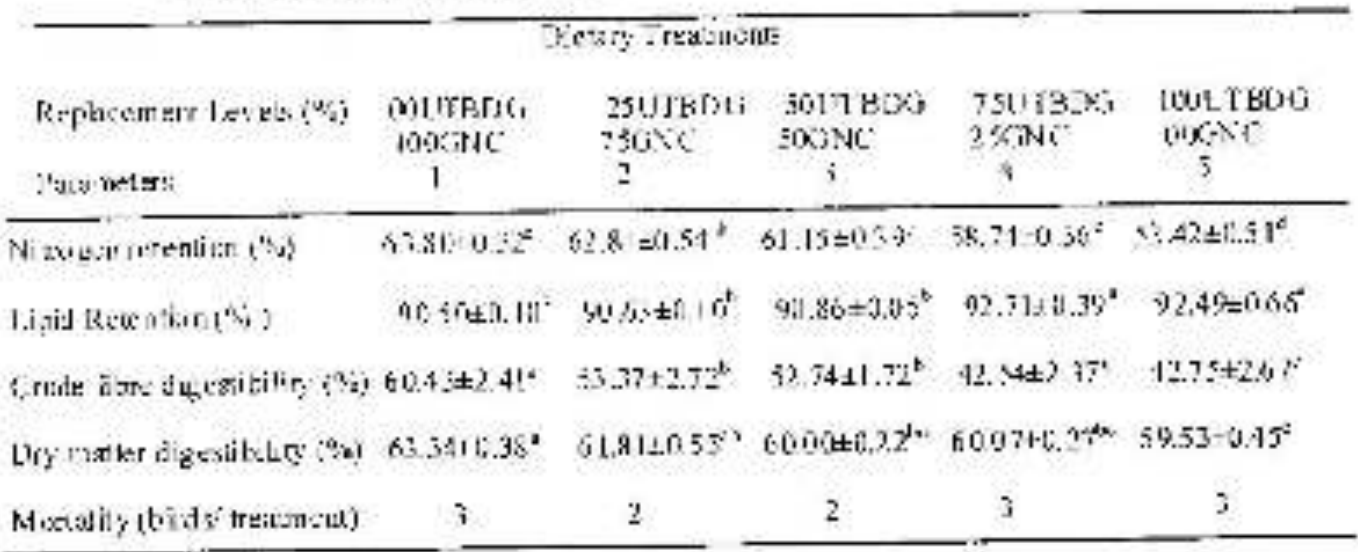

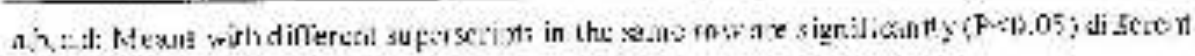




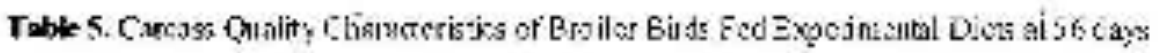

\begin{tabular}{|c|c|c|c|c|c|}
\hline \multirow[b]{2}{*}{ Requsement Ievels ithi) } & \multicolumn{4}{|c|}{ Пispry Trentrross } & \multirow[b]{2}{*}{$\begin{array}{c}\text { I0ECTEOO } \\
\text { 0tanc } \\
5\end{array}$} \\
\hline & $\begin{array}{l}\operatorname{coctax} \\
\text { Lcost }\end{array}$ & $\begin{array}{c}\text { Xg } 251 \mathrm{IT} \text { DG } \\
25 \mathrm{SC} \\
2\end{array}$ & $\begin{array}{c}\text { 50:T3DS } \\
30 \mathrm{CN} \\
\vdots\end{array}$ & $\begin{array}{c}\text { 7SUTBDS } \\
\text { 25GNC } \\
4\end{array}$ & \\
\hline Linc weight fik! & $2.6+6.21$ & $260+0.2 \mathrm{~J}$ & $2.05+6.24$ & $1.61-4.0$ & $1.8+i t .12$ \\
\hline Pandoot weight $\mathrm{kggi}$ & $1.8 \% \pm 4.19$ & $1.8 .2=1.8$ & $1.81 \pm 0.20$ & $1.52+6.68$ & $1.73+5.20$ \\
\hline Dessed rejuht (kịi & $1.68+0.26$ & $i .60=0 . .7$ & $1.71+0.13$ & $1.4 \times 0$. ․ㅏ & $1.58+3.18$ \\
\hline Cresed waght & $8168 \pm 4$ दी8 & $84.50+c .05$ & $3601 \pm 1.18$ & $90 x+3.40$ & $55.20+0.18$ \\
\hline Fis:-urated W & $1.500 .2 \%$ & $1,431.6 .18$ & $(8) \perp i), 15$ & $12(4 \pm 1,12$ & $13 ; \pm 0.1 ?$ \\
\hline 'Pn werateid Wri & $71.33+35$ & 7A.IULA & $7 \times 82+085$ & $736 \times 240$ & $7^{*}=1 \pm 0$ \\
\hline Had wrigl o lk kut & $1: 06: 001$ & a.:Lst:1.:1 & 10.05 .0101 & $|x 05 t \leq 1.3|$ & $a=0 \operatorname{cin} 00$ \\
\hline Shank wiglu ikg; & $t:[2-1] 01$ & yog tol.t. & a.to-uce & D. $100.5 \mathrm{KI}$ & 19.109 .01 \\
\hline Himat veidut & $27.53 \div \mathrm{L} .53 \mathrm{k}$ & $28 \sigma j+1 . \omega$ & $29.15-0.49$ & $27 . x-0.53^{d}$ & $24.41-112 \%$ \\
\hline 'Diut: weipht & $15,541 \cdot 0.94$ & $24.16=1.16$ & $19.52 \times 1.33$ & $18.80=0.25$ & $21.1 \leq \pm 2 . \mathrm{i} 8$ \\
\hline Thents ix & 14.75ㄹ: Is & $1372=125$ & $15,54 \pm 1 t, 83$ & $15.04=0.23$ & $15.28+1.6$ \\
\hline Then xelght & 16. & {$[6,3 \in[0,4]$} & $14.5 \pm 1 . \overline{4}$ & $17,12=0145$ & $17.82 \pm 1.15$ \\
\hline "Yill Ewtzllt & $1254 \pm 1.7 \mathrm{n}$ & $11.57=12.12$ & $1351 \pm 1.31$ & $12.21+0.76$ & J180̄t].13 \\
\hline Feckxcent. & fastilstit & 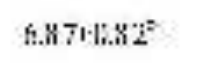 & 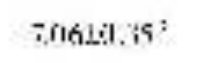 & a.21Lk.tos & $79 k+i 164$ \\
\hline
\end{tabular}

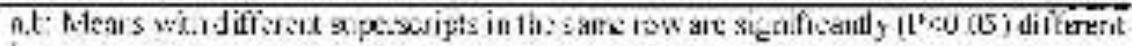

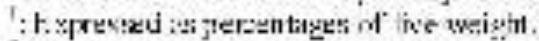

: Frprescet asperentmoes of arisocratis washt. 


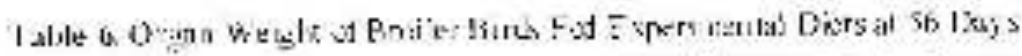

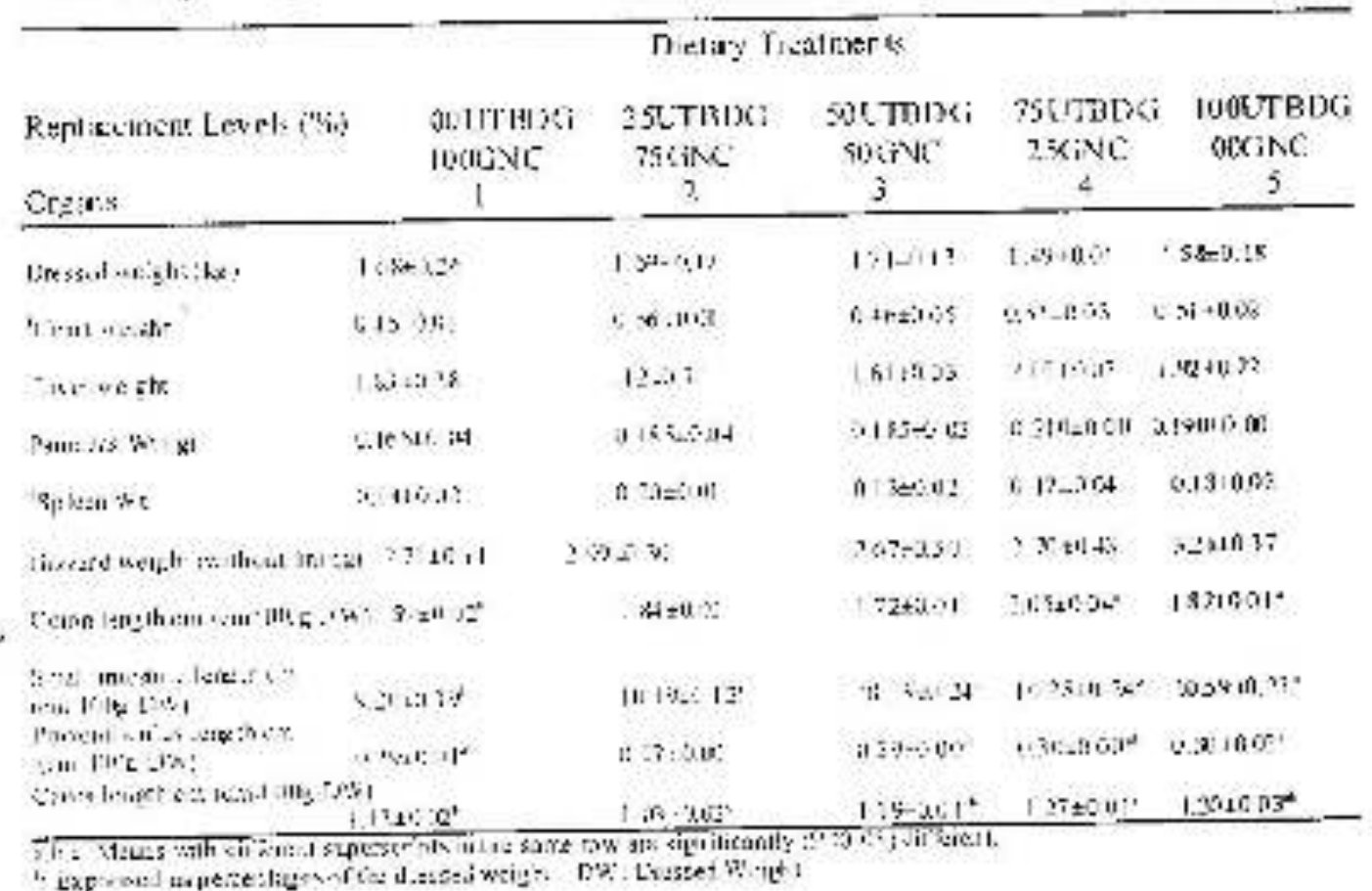

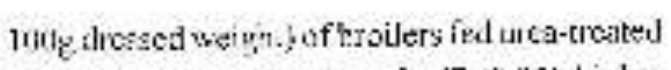

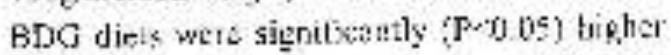
than those of biods sn the control diet

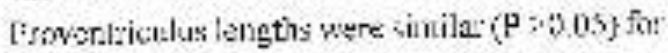
atl nearment gruters $\mathrm{cxoept}$ tor the $25 \%$ dir:

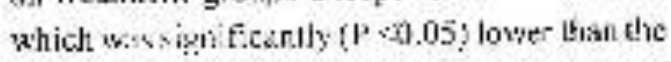

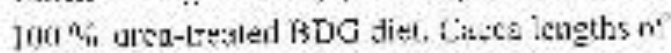

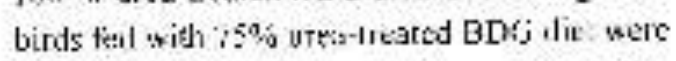

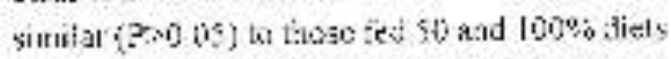

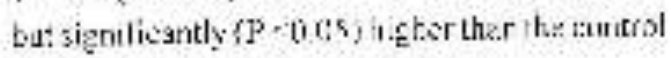

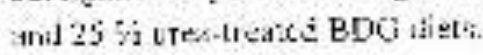

\section{Discussion}

The acorperation of ureaterated and fe-rinered BIXi irro dicts of cosiler tinisher bists

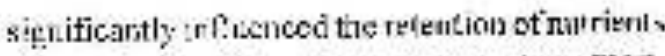
jince ol l:as a thighe Thre conien than GNC. Vinogen relerrition (NR) rales for froiler birds

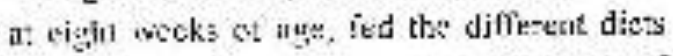

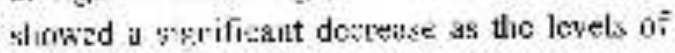
ureil treatod BLKj increascd in the cliets. Tuys result agretel with the sind nes of Nwenge ind Okakhotro (2000) who reporled decreased protein anal arnias acis iligestibilicy dee to

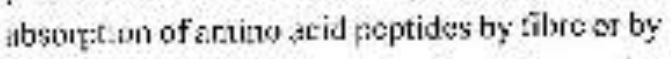
preventing theis absorglinn from the gasten

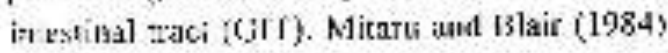
(eported that the extent of the docreuse coppeats gre the degrese o. Hignification of the fibre. The

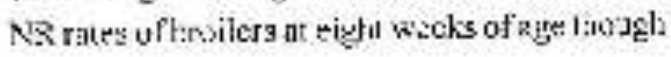




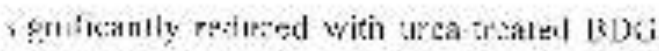

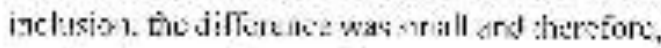

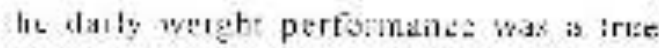

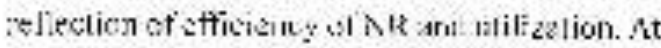
$\therefore$ he wetks, as ü. lipis relentivi of hwiler linisher birds was somplelriy reversed witls

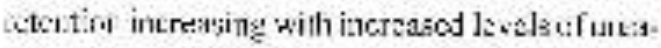
reased $A D G$ inclosion in the liels Lepid retertien wes signilicanty higher in dies wit: 75 and loive inciusions that the rit te- createneot:

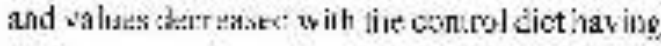
the loast retsotica salue. This analy be itributest

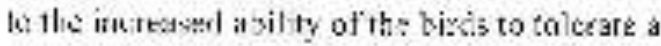
hyerer propotion of crade lithe in Larir dies; al this ase. The fact ather at the tinisher period ansmy

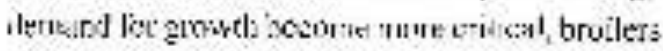

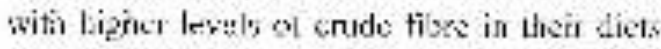
arr inese likely te fid: 1.1 the the axilable

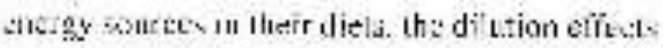

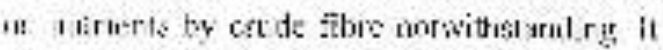

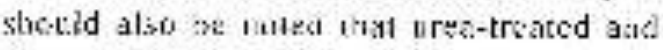

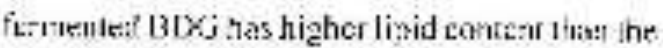
untreated BOG and 11!us aty have contributed to

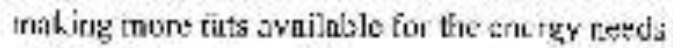
of tirishing buai ers. The :aтpessuto:y growat. che:-ve: ir broilers zuring the neliod us revexted by the sitailan ity in wetigyt perlocrumes may hawe resulec: from a more ettecicat moh lizat in arel utlization of avaisable chels $\because$ ir the unea-treated RIX) diels is the Foiler birds metare. Al engh weck of ago. ceute fitse and disy reattor dicestilsilitiex Ileconesed with incresed inc lusiurı

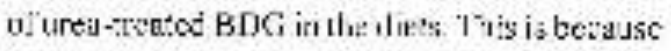
increasity, the aTe: treated BOG zalse increaties

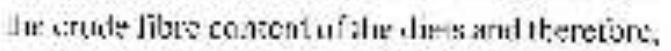
rione fibre leqid for toviless on Itese diels to

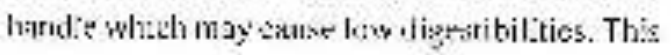

-egalt was in agrcencit sill: lie findings of scwetal atuthrs whu ecorted as inverse relationship tetween dictary hirre digessibilit?

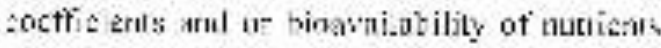

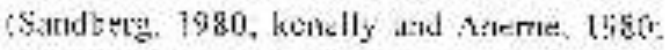

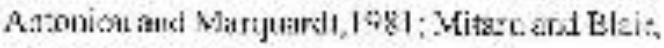

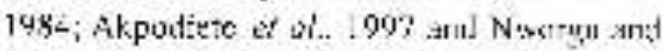

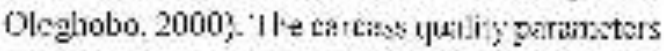

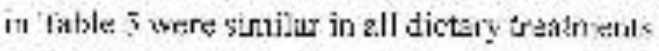

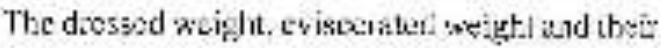
expression is a percertage of liwe racizit in als dietary treal fentis were si nilat und values vhimres in this study are consistent with ilis ruge of velues tepuntes. ly rlarye abot M:rion (1973): Drwatibent at at. (1981): Onwidike

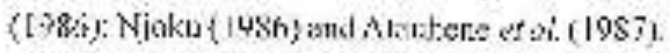

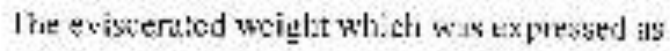
a percontage of lie five weight is a meraclistle

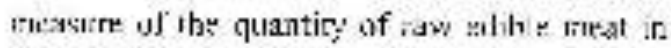
the finished broiler since the cercass

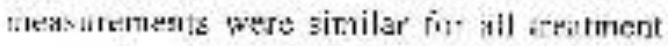
arsups, it can bo inferied lial utea-cteared ans femerted 1306 and CNC ale simila:

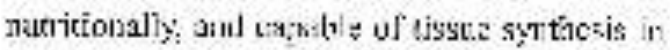
fir ivies arvilers under the sare envirunmert. The ctit-l:p parts such as back, droinstick, th.gh and wirg weights iexprossed as sercenlilete o: *visweratsd weiglen of bruler jirds were not significantly differrent wxcopt for breast :n 1 a ach peights. The valties obt:iend lell within the range

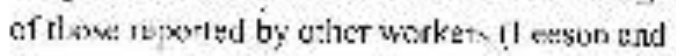
Samners, 1980, Broinlbent et ut., 1581, Vjriku, 1485] The similarity of the areast weights lor traatmsals with $0,25,50$ and $2 \leq 4 \%$ cplacernent levels contion to the perlemance il sther cut-uls :xarts libe poes paffolular ta of h-tait weigh! by the $100 \%$ keplacterent lowel 


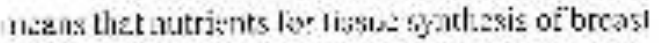

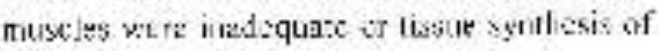

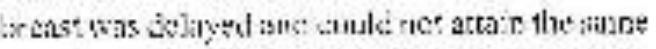

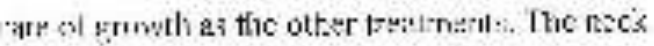

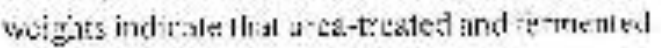
libsi ncopelation serer: lot enc.stage the

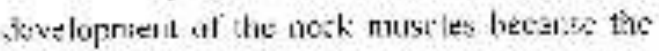

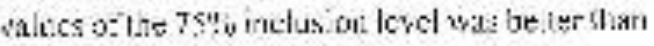
thet cantrol while other Ire-losert lewa vere

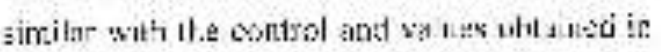

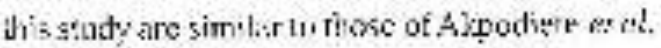
(16).

The orein wethlts of lictri, liver, paricteas,

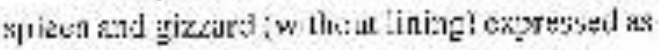

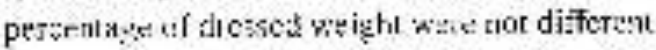
amora the deary trestmens trin is a welituasion of the fic: lla the insorporation

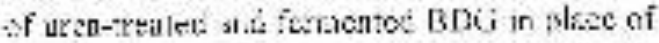

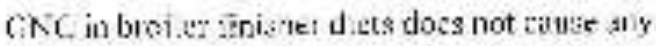

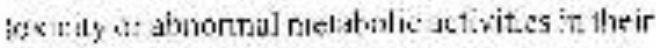

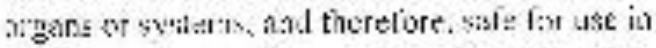

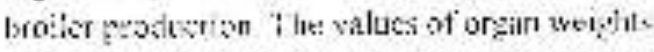

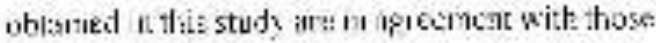

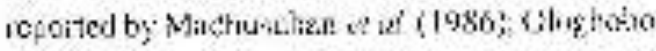

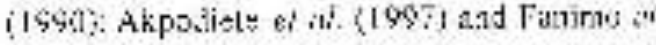

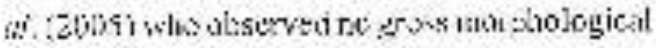
changea nos tristresalhologicel mestifestimu in the urgens of bjods :et diets compoundest from sarious feed ingrediente

The solon. sa.a.l irtcstine, prover oric Jlu?

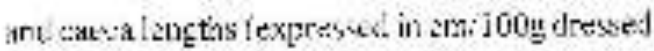
wigbt were significunty inumend by dictary Is atments. The colsw and sme.ll intest re lenghs

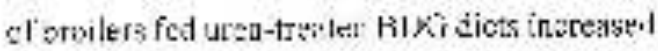
significan:ly with incessing level of urca-

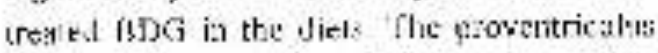

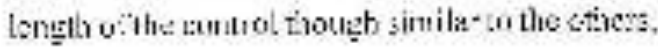

|erpll tresesed as level af unca-roated BDKJ i.cheseil in rles Liets. Caeca lenyhis followed

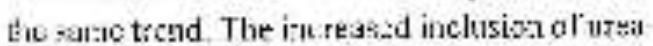

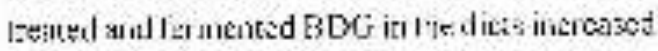

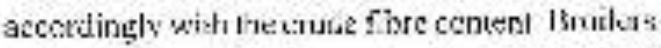

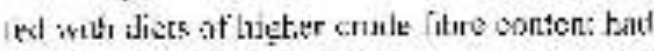

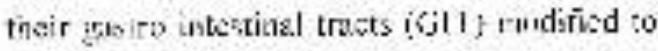

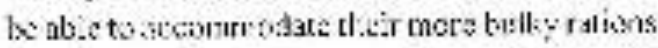

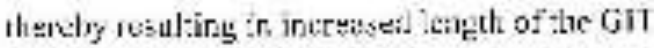
ard ils Eurnousent sccrions: Thi izsult is supported by an ex:edent reports of Siawey zud

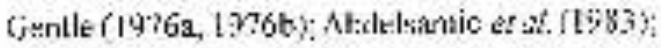
Krogdahl (1985); Hetlans and Svitus 1200:? :

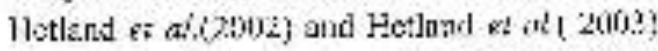

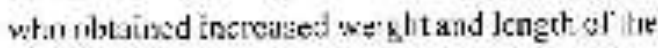
GIT in toniless and Japuese ciasil when high filyc dicts wers Ind

\section{Conclusion}

Bassd on the conipanablo tesults obtanneit from tareass clatizy ihasateristics orgar.

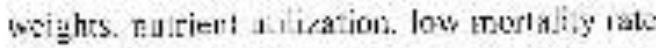
int llic alssence of grows muphological thanges

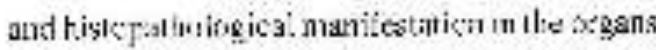
of bi.ds, the uje of urea-tesatod and termertesl

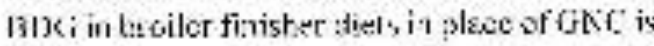
bishly idvocaul. Ulesa-treated acul icomentod

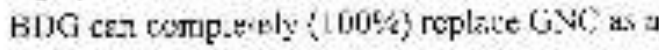

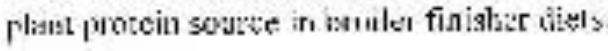

\section{References}

Sbrelsanic, R. E, Ranuvreers, K. Y.P., und Yanc, W.E. 1953. T.1 artigenes of tibre con ir ili and plysicel texluse pi t'm

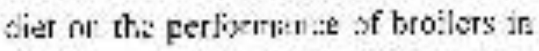
the Trepes, Hric. Poult. Sci. 7A. ins 200 . 


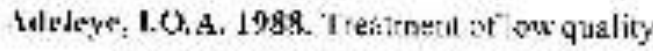
rouglage; isnd ilarenonic tasiciue;

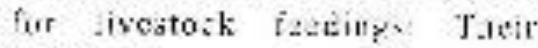
techuostey. spplesasilicy and tlaruabulitr o local cont liun Inrired zalper prosenteil at the wo:kshop on A]terative Tormulation of lives ack feeds in Nigeria now $7,2 \leqslant 1$ 1988. Inivasily of Ixwan, Jbadz.r. Niger a

Adeuแmuri, A. A. 1973. Fvalualuen u! breker's tried elsins :n thets of grwwing

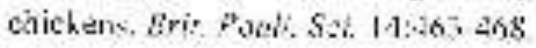

Asluku, A. O. 1993. Twy Tolise laculty of Azrituliare, i) Ahmati. Beito University. Scmarı Zaria Nigeria

Akpudiete, O.J.: Oregliubo, A. D. abd Ayuiule, O. \& 1997. Replacontel walue of maleget mosl to fothreai in broiles stickers duets In. Lirestick J'sndu:is l'ro: of z" Aan. Cosıl. snirr Scit.

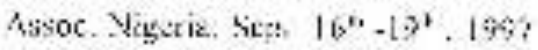

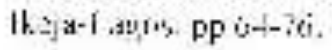

Andenian, T. and Marquarih, R. R. \&!)81. Th: infuente cl tye pontesan on the grow of chicks. Poizis. Sci. 59:189s.

\section{Association of Chficial Anslytical Cheruints,} (A.O.A.C) 1990. Dif:cial ane hunds of anilysis. . $\Sigma^{ \pm}$ed tive. Whargton $\mathrm{D}, \mathrm{C}$.

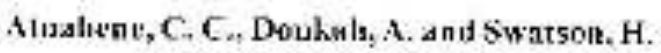
195- 0:1 palru sinry ats a parial

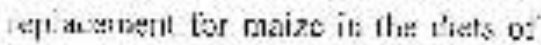
bro:ker shickers Arim foed Sin Twin. ! $3: 1.2 \%-157$

Broadbcut, L. A., Witeson, B. J, nud Fsher, C. 198I, the ismposition st ath hruilur whickens al to days of age. ottput,

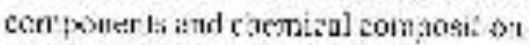

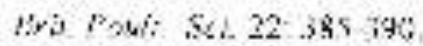

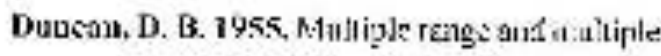

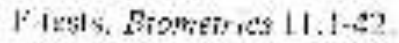

Faniano, A. 1), Ba megbose, A. M., Abiala, H. 0., Allediran, M. and Olanizan, A, I 2005. Carca's yiald and blinid parsmeless of broilse chickens lend

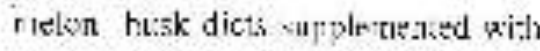

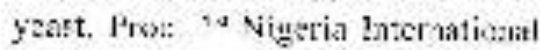

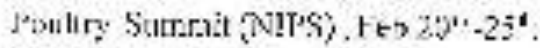
2005. Ota, Ogun Sline, Nizceria.

Faniyd, (,.1., Ologhobo, h. I., Alstriend. G. A. and Alaha, 0. O. 19!7. Clecrical cliarice crization of azilratec and

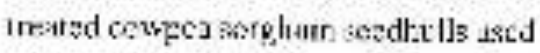
ils pouttey feed ingradient. Ir. Livesteck Product3. Pat: $7=1$ Ams.

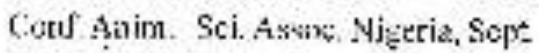
$15^{\prime}-19^{\prime} 1097$, Ike) 4-Lagos.. pp. 11-??

Fauryl, C : F. uncl OJogbobra, 4. 1). 199!. Efrocts af esplacing buter's driod etsins w.kI 
T. $\%$ and urea-trandest coupea and sygham wedhsils in trovilat ilits irept flum. Fyos in wat. 2 69-85.

Haỵse. 1. L. altd Miricin. W. 31. 1)?3.

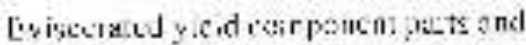

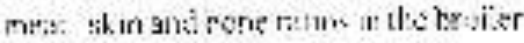
chicker. Mis Sti 52 : $718-722$.

Hectugu, H. and Svibux, B. 2haJ. Effect of̈ ta: halls ua portiorsalece , st aspicily and teed jassnes' lint in preilet

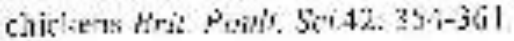

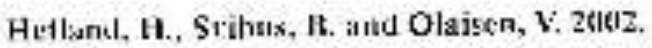
Uffect of leeding whole ceicals wn perlurmences, sterch digestibilicy ant: duoderat particle size sisiribution in butler chickens. Brot. Potid S.6 13: $1 ! 6-1: 3$

Hetland, It., si ihus, 8 , and Kruxelıăl. A, 2003.

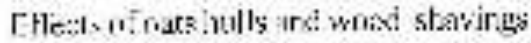
or. digertiom a kroilers and layers iod licts ba:ed un whale or gromal whicat

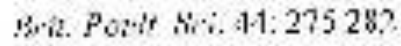

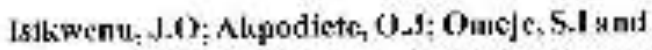
Olcughare. C,0. 2aras. Efient at repluciny, zutindrut cin will arez-

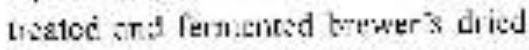

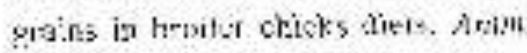
Amsarest in 'i 5 (1):795-810

Kenelly, J, J. atid Aherne, r.. X. J980, the effecl of the formusatisa to contain d.fferen levels of on ary and protein on kipesthelity cocticisnts un swine. Cur. I Anim Sei. $69: 77773$.

Krogdahi, a. 1986. Ar. futrents ailecurt?

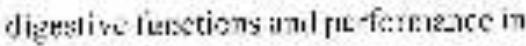
nouler Pros ?" Euro Pust. Cort. Paris. 1 pl 1 p. $239-248$

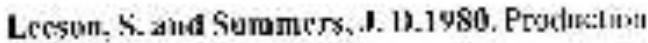
and cuscass tharactealiatics ot ite fovile dicksos. Povis. Sei. 5\%: 677 652.

Macl lassulaan, K. T., ltanesb, H, P., Geatra. $r$, Sasaoki, K. anil Singh, Y. 14H6. Derexication of cermecreial lintered meal fir are in beciler rations. Polih Sc. 65: 14a1:1.

Vencenold. P., Edwaris, R. A. and Greushalgh, J.F.I\}. 1995. Amita:

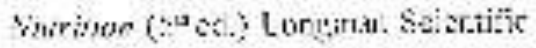
z.nt Teshnis. Englend

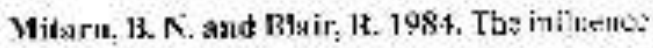
if dictayy figre sumice on grsunt, liect ellic atcy and dignesulility of diy mister inul pertein in zats of Sra Fef Agrir. 5. $525-62 \mathrm{~h}$.

Njoku, P. C. I!986. lifect of dietary sucotbic

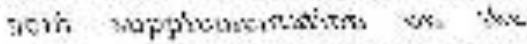
sertivenisuce of besiler thickens in : tropich environaen: Asim. Feet Sici.Jstinal 16:1?-24 


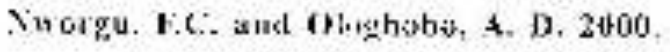

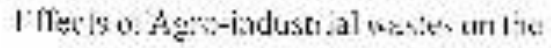

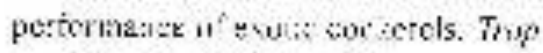
itim Sil 3il: 27-21.

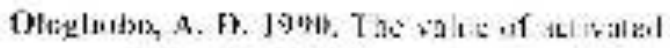

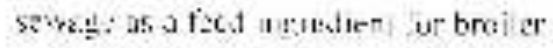
irore Ining Prot twent. 1:113-123.

Ouw ulike, 17.6: 1593, Lavory ard Proten

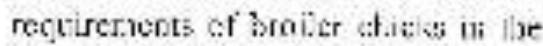

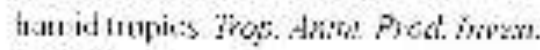
$8 \cdot 39-4 \cdot 4$

Onw redike, 0, C. 1986. Paliu keroct in_al as .y

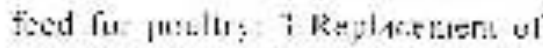

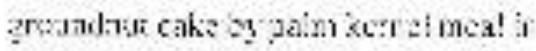
builar diet viling jesd sai. Tevimó 15: $195-262$.

Itichascision,, , E., Warts, A.B. and J.pis. I:

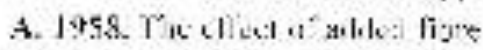

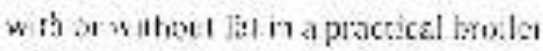

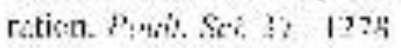

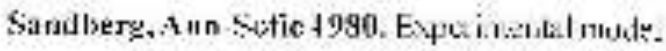

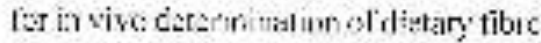

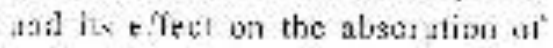
1.wisus in tl:- solall minstine Brit.

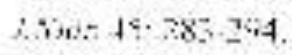

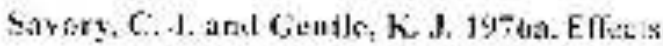

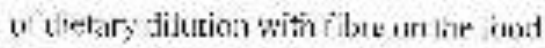

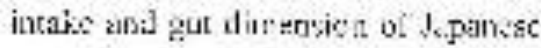

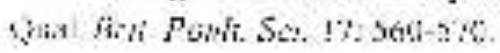

Savory, C.. I. und (Aentle, K, J. 1976k. Clianges

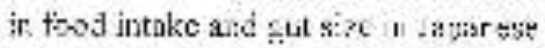
Quail on tessor en tom napalation of jielity tibre content. Bit., Pogit. She $12: 2 ; 1-78 \%$.

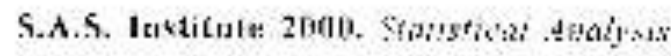
Strowe. tiser's Guice, Gare, N. C AsA. $\mathrm{r} 44$

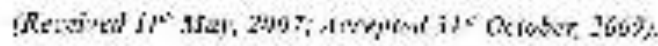

